\title{
Resistance to Restoration
}

There is something about restoring ecosystems that seems different from all other environmental activities. Perhaps it's because restorationists help create nature; we don't simply protect it, manage it, or regulate it. Not everyone agrees that we create nature. Philosophers Eric Katz (1996) and Robert Elliot (1997) called restoration a forgery, and our efforts have come under attack by elements of the public (Shore, 1997). For years, I have been curious about the distinction between restoration and other conservation strategies and about why restoration sometimes provokes resistance. In this editorial I contend that restoration practice provokes antagonism because it represents a worldview that differs from that of conservation, environmentalism, and most of the "hard" sciences.

Restoration can be traced in part to science in the Renaissance. The intent of science at that time was to elucidate the immutable laws of nature that God had created (Davies, 1992). This was the god of classical western theism, who is accepted today by most believers of Judaism, Christianity, and Islam. God, according to theism, is distinct from the universe he created and rules, and theists deny the possibility of ever achieving equanimity with the divine. Newton, Boyle, and other seventeenth century scientists believed that this wholly transcendent god was responsible for the creation of the universe and for putting matter into motion (Griffin, 1988). With the gradual secularization of authority, the role of God in science came to be ignored, and theism was eventually replaced by materialism, which posited that nothing but matter actually exists (Smith, 1989). The principal tenet of materialism was reductionism, which claimed that higher things were explainable by lower things and that the whole could be explained in terms of its parts (Griffin and Smith, 1989). Even though materialism defined nature as mechanical, and without vivification by spirit, materialists retained cultural values concerning nature that were accepted by theists.

The notion of the transcendent god upon which classical western theism was predicated arose relatively late in Judaic thought-approximately 200 years before the common era-and garnered little notice among Christians during the first three centuries following the crucifixion of Jesus. This conception of god was adopted by the synod of Nicaea in 325 but was ignored by church authorities for the next six decades (Armstrong, 1993). Augustine revived the concept when he declared in 379 that God created heaven and earth out of nothing-creation ex nihilo. Because Augustine considered humans to have been created out of nothing, they were only creatures and could not participate directly in God's being and nature. Augustine's doctrine appeared at a fortuitous time for the Christian fathers, who used the concept of creation ex nihilo to strengthen their ecclesiastic authority and to merge the Church with the Roman Empire (Tillich, 1967; Pagels, 1988). These pragmatic benefits helped to ingrain Augustine's doctrine in Christian theology.

I contend that the modern idea of wilderness, which has played so large a role in the North American conservation movement, stems ultimately from Augustine's concept of creation ex nihilo and underlies the skepticism that critics have voiced for restoration. Augustine leaned heavily on the Judaic legend of Eden, which asserted that creation was completed in a few days at the dawn of time (Chadwick, 1967). This same Augustinian thinking appears in our concept of pristine wilderness. Wilderness is cherished as the work of divine creation. Since humans-having been created ex nihilo-cannot participate in creation, our proper role is to safeguard nature from damage. The result has been protectionist policies that have led to the establishment of preserves, which we can only visit and where we can only leave footprints. To do anything else, even prescribed burning, would be tantamount to "playing God." If carried to their extreme, such policies deny the authenticity of ecosystems that self-organize in response to restoration practice.

Because we participate in the dynamics of ecosystems as we restore them, restoration practice is in essence antithetical to the idea of pristine wilderness. As restorationists, we become performers in an on-going process of creation, and in doing so we defy a basic assumption of environmentalism. No wonder we invite resistance. We are charged with "nature faking" by theists and also by materialists whose values concerning nature were apparently derived from theism even though they are no longer overtly religious.

If restoration practice does not conform with classical western theism, where are its philosophical affinities? I propose that restoration practitioners work from a worldview called the perennial philosophy by Aldous Huxley (1944) and the primordial tradition by Huston Smith (1989). The basic premise of the perennial philosophy is that the higher cannot be explained by or be derived from the lower (Wilbur, 1982). This, of course, emphatically contradicts the principle of reductionism. The perennial philosophy accepts an impersonal and immanent divinity that corresponds to the Vedantic concept of Brahman. This divinity is central to esotericism in all religious traditions (Schuon, 1984) and to Hermetic, Cabalistic, and Neoplatonic philosophies (Griffin, 1988). Schuon (1984) explains that this divinity, ".....annihilates all apparent reality other than him...", 
which means that this divinity, or god, cannot be differentiated from its creations. Humans, therefore, are innately divine and are inseparable from the rest of nature, which is also divine. Creation was not a historic event but is an on-going process in which humans participate. The restoration of ecosystems is easily identified as an expression of this creative process.

\section{Are we leasing a prefabricated}

\section{universe from a transcendent god?}

\section{Or are we investing in a universe that} we ourselves are making in concert with an immanent divinity?

In contrast, restoration ecology - as distinct from restoration practice-traces its antecedents to Renaissance science and theism. As restoration ecologists we conduct ecological baseline inventories upon which we model restoration. We test new methods of restoration practice. We monitor our project sites. We evaluate the ecological effectiveness of our restoration efforts. In all of these activities we are dispassionate scientific observers rather than the creators of an enriched biosphere through restoration practice. As restoration ecologists, we are no longer expressing an innate divinity and oneness with nature. Instead, we are operating from the opposing vantage point of creation ex nihilo.

The simultaneous acceptance of two contrasting worldviews is not unprecedented in science. Physicists explain many phenomena in accordance with reductionism. However, to interpret very large-scale physical events associated with relativity theory and very small-scale quantum events, physicists switch to a worldview that closely parallels the perennial philosophy (Smith, 1985). These dual worldviews are somehow complementary, and restorationists as well as physicists need both.

With the sun bearing down on our backs, we remain oblivious to these epistemological cross-currents as we blithely engage in restoration. But perhaps in a reflective moment we may ask ourselves: Are we leasing a prefabricated universe from a transcendent god? Or are we investing in a universe that we ourselves are making in concert with an immanent divinity? As restorationists we do both.

Andre F. Clewell

Andre Clewell owns A. F. Clewell, Inc., which specializes in ecological restoration and is located at 98 Wiregrass Lane, Quincy FL 32351 USA; 850/875-3868; fax 850/875-1848; e-mail: clewell@tds.net

\section{ACKNOWLEDGMENTS}

I thank Susan Bratton, Robert S. Ellwood, J. Ron Engel, and John Leonard who reviewed drafts of this article.

\section{REFERENCES}

Armstrong, K. 1993. A History of God, the 4,000-Year Quest of Judaism, Christianity and Islam. New York: Ballantine Books.

Augustine, A. 379. The Confessions of St. Augustine, Bishop of Hippo (Outler Translation, Book 12, Chapter 7). Christian Classics Ethereal Library. http://www.leaderu.com/cyber/books/augconfessions/bk12.html.

Chadwick, H. 1967, revised 1993. The Early Church. London: Penguin Books.

Davies, P. 1992. The Mind of God. New York: Simon \& Schuster.

Elliot, R. 1997. Faking Nature: The Ethics of Environmental Restoration. London and New York: Routledge.

Griffin, D. R. 1988. Introduction: The Reenchantment of Science. Pages 1-46 in Griffin, D. R., editor, The Reenchantment of Science. Albany, New York: State University of New York Press.

Griffin, D. R. 1989. Premodern and Postmodern Philosophical Theology: A Response to Huston Smith's Program. Pages 17-60 in Griffin, D. R., and H. Smith, Primoridal Truth and Postmodern Theology. Albany, New York: State University of New York Press.

Huxley, A. 1944. The Perennial Philosophy. Perennial Library, New York: Harper \& Row.

Katz, E. 1996. The Problem of Ecological Restoration. Environmental Ethics 18:222-224.

Pagels, E. 1988. Adam, Eve, and the Serpent. New York: Vintage Books, A Division of Random House.

Schuon, F. 1984. The Transcendent Unity of Religions. Wheaton, Illinois: Quest Books.

Shore, D. 1997. The Chicago wilderness and its critics II. Controversy erupts over restoration in Chicago area. Restoration $\mathcal{E}$ Management Notes 15(1):25-31.

Smith, H. 1985. Forgotten Truth, the Common Vision of the World's Religions. New York: HarperCollins Publishers.

1989. Beyond the Post-Modern Mind, 2nd edition. Wheaton, Illinois: Quest Books.

Tillich, P. 1967. A History of Christian Thought, from Its Judaic and Hellenistic Origins to Existentialism. Edited by C. E. Braaten. New York: A Touchstone Book, Simon and Schuster.

Wilbur, K. 1982. Physics, Mysticism, and the New Holographic Paradigm, a Critical Appraisal. Pages 157-186 in Wilbur, K., editor, The Holographic Paradigm and Other Paradoxes. Boston \& London: New Science Library. 